\title{
Characterization of Agrobacterium tumefaciens PPKs reveals the formation of oligophosphorylated products up to nucleoside nona-phosphates
}

\author{
Celina Frank ${ }^{1} \cdot$ Attila Teleki $^{2} \cdot$ Dieter Jendrossek $^{1}$ (I) \\ Received: 13 July 2020 / Revised: 28 August 2020 / Accepted: 4 September 2020 / Published online: 6 October 2020 \\ (C) The Author(s) 2020
}

\begin{abstract}
Agrobacterium tumefaciens synthesizes polyphosphate (polyP) in the form of one or two polyP granules per cell during growth. The A. tumefaciens genome codes for two polyphosphate kinase genes, $p p k 1_{A T}$ and $p p k 2_{A T}$, of which only $p p k 1_{A T}$ is essential for polyP granule formation in vivo. Biochemical characterization of the purified PPK $1_{\mathrm{AT}}$ and $\mathrm{PPK} 2_{\mathrm{AT}}$ proteins revealed a higher substrate specificity of PPK1 $1_{\mathrm{AT}}$ (in particular for adenine nucleotides) than for PPK2 $2_{\mathrm{AT}}$. In contrast, PPK2 $2_{\mathrm{AT}}$ accepted all nucleotides at comparable rates. Most interestingly, PPK2 $2_{\mathrm{AT}}$ catalyzed also the formation of tetra-, penta-, hexa-, hepta-, and octa-phosphorylated nucleosides from guanine, cytosine, desoxy-thymidine, and uridine nucleotides and even nonaphosphorylated adenosine. Our data - in combination with in vivo results - suggest that PPK $1_{\mathrm{AT}}$ is important for the formation of polyP whereas $\mathrm{PPK} 2_{\mathrm{AT}}$ has the function to replenish nucleoside triphosphate pools during times of enhanced demand. The potential physiological function(s) of the detected oligophosphorylated nucleotides await clarification.
\end{abstract}

\section{Key points}

- $P P K 1_{A T}$ and $P P K 2_{A T}$ have different substrate specificities,

$\cdot P P K 2_{A T}$ is a subgroup 1 member of $P P K 2$,

- $P P K 2_{A T}$ catalyzes the formation of polyphosphorylated nucleosides

Keywords Polyphosphate $\cdot$ Polyphosphate kinase $\cdot$ Agrobacterium tumefaciens $\cdot$ Nucleotides

\section{Introduction}

Polyphosphate (polyP) is an inorganic polymer in which phosphate residues are linked by energy-rich phosphoanhydride bonds. It can be formed either abiotically (vulcanism) or biologically by the action of polyP kinases (PPKs in prokaryotes) or other enzymes (in eukaryotes). PolyP is ubiquitously distributed in species of all domains of

Electronic supplementary material The online version of this article (https://doi.org/10.1007/s00253-020-10891-7) contains supplementary material, which is available to authorized users.

Dieter Jendrossek

dieter.jendrossek@imb.uni-stuttgart.de

1 Institute of Microbiology, University of Stuttgart, Allmandring 31, 70569 Stuttgart, Germany

2 Institute of Biochemical Engineering, University of Stuttgart, Stuttgart, Germany life (Kornberg et al. 1999; Rao et al. 2009; Kulakovskaya et al. 2014). In most prokaryotes, polyP is present in form of granule-like inclusions (polyP granules or voluntin granules) with diameters mostly in the range of 50 to $200 \mathrm{~nm}$. In yeasts, polyP can be accumulated up to $\approx$ one quarter of the cellular weight in vacuole-like compartments (Christ et al. 2020a). PolyP represents a reservoir of phosphorous and apparently is also involved in various forms of stress resistance such as tolerance against heavy metals, elevated temperature, or reactive oxygen species and can fulfill functions in virulence, motility, biofilm formation, and cell cycle control (Rashid and Kornberg 2000; Rashid et al. 2000; Nikel et al. 2013; Chuang et al. 2013; Gray and Jakob 2015; Racki et al. 2017). In humans, polyP participates in blood coagulation but is also involved in neurodegenerative diseases (Lempart and Jakob 2019).

In prokaryotes, two types of PPKs are known to catalyze the reversible formation of polyP from ATP: PPK1 type PPKs have a molecular mass of $\approx 80 \mathrm{kDa}$ and consist of an $\mathrm{N}$-terminal $(\mathrm{N})$ 
domain, a head $(\mathrm{H})$ domain, and two C-terminal domains (C1 and C2) (Ahn and Kornberg 1990; Zhu et al. 2005). The E. coli polyP kinase is the first described PPK and the prototype of type 1 PPKs (Ahn and Kornberg 1990). PPKs of the PPK2 type have roughly only half of the molecular masses of PPK1s (MW around $40 \mathrm{kDa}$ ) and are divided into three subtypes dependent on their substrate specificities for nucleoside di-phosphates (subtype 1), nucleoside mono-phosphates (subtype 2), or both (subtype 3) (Motomura et al. 2014). Bacteria can have only the PPK1 type of PPKs, only the PPK2 type of PPKs, or both types of PPKs (PPK1 and PPK2) (Rao et al. 2009). Several recent reports describe that some PPK2s are able to form nucleotides with four (Mordhorst et al. 2019; Ogawa et al. 2019; Hildenbrand et al. 2019) or even five (Mordhorst et al. 2019) phosphate residues.

The $\beta$-proteobacterium Ralstonia eutropha (Cupriavidus necator) is somehow special as its genome has seven ppk genes. Indeed, two PPK1s (PPK1a and PPK1b) as well as five PPK2s (PPK2a-PPK2d) have been identified in $R$. eutropha (Tumlirsch et al. 2015). One of the PPK2s, PPK2c, turned out to be highly active in vitro and catalyzed the formation of microscopically detectable polyP granules in vitro (Hildenbrand et al. 2019; Hildenbrand et al. 2020). The other PPKs of $R$. eutropha have not yet been investigated. The $\alpha$ proteobacterium Agrobacterium tumefaciens has two ppk genes (Atu0418 and Atu1144) that encode a type 2 PPK $\left(\mathrm{PPK} 2_{\mathrm{AT}}\right)$ and a type $1 \mathrm{PPK}\left(\mathrm{PPK} 1_{\mathrm{AT}}\right)$, respectively. In our recent study (Frank and Jendrossek 2020), we showed that polyP in Agrobacterium tumefaciens is stored in "ordinary"
polyP granules and not in membrane-enclosed acidocalcisomes as previously assumed (Seufferheld et al. 2003). In the present study, we determined the in vitro properties of purified $\mathrm{PPK} 1_{\mathrm{AT}}$ and $\mathrm{PPK} 2_{\mathrm{AT}}$. It turned out that $\mathrm{PPK} 2{ }_{\mathrm{AT}}$ is rather promiscuous with respect to its nucleotide specificity but had the so far unique property to catalyze the formation of oligophosphorylated nucleotides up to nonaphosphorylated nucleotides.

\section{Material and methods}

\section{Bacterial strains, plasmids, and culture conditions}

Table 1 lists all used bacterial strains and plasmids of this study. A. tumefaciens C58 was the source of ppk genes. Genomic DNA was used to clone ppk1 (Atu1144, hereafter $p p k 1_{A T}$ ) and $p p k 2$ (Atu0418, hereafter $p p k 2_{A T}$ ). Escherichia coli JM109 and E. coli BL21(DE3)/pLysS (Novagen) served as hosts in cloning procedures and gene expression, respectively. Cloning of $p p k 1_{A T}$ into the $\mathrm{pET} 22 \mathrm{~b}$ expression vector $\left(p p k 1_{A T}-h i s_{6}\right)$ was done with BamHI and SacI as restriction and cloning sites. Ppk2 ${ }_{A T}$ was cloned into pET28a (his $6^{-}$ $p p k 2_{A T}$ ) with $N c o$ I and BamHI. The pET22b-ppk1 $1_{A T}$ and pET28a-ppk $2_{A T}$ constructs were transformed into $E$. coli JM109, verified by PCR amplification and sequencing, before finally transformed into the expression strain $E$. coli BL21(DE3)/pLysS.

Table 1 Bacterial strains and plasmids used in this study

\begin{tabular}{|c|c|c|}
\hline Strain/plasmid & Relevant characteristics & Reference \\
\hline Escherichia coli JM109 & Cloning strain & DSMZ3423 \\
\hline E. coli $\mathrm{BL} 21(\mathrm{DE} 3) / \mathrm{pLysS}$ & & Novagene \\
\hline Agrobacterium tumefaciens $\mathrm{C} 58$ & Wild type, $\mathrm{Km}^{\mathrm{s}}$ & $\begin{array}{l}\text { Goodner et al. } \\
\quad(2001)\end{array}$ \\
\hline A. tumefaciens C58 $\Delta p p k 1 \Delta p p k 2$ & Gene deletion of $p p k 1_{A T}(a t u 1144)$ and $p p k 2_{A T}(a t u 0418)$, polyP-deficient, $\mathrm{Km}^{\mathrm{s}}$ & $\begin{array}{l}\text { Frank and } \\
\text { Jendrossek } \\
(2020)\end{array}$ \\
\hline pBBR1MCS2::PphaC-eyfp-cl & $\begin{array}{l}\text { Broad host range vector for construction of gene fusions with eyfp, confers } \mathrm{Km}^{\mathrm{r}} \text {, } \\
\text { constitutive expression from PphaC }\end{array}$ & $\begin{array}{l}\text { Pfeiffer et al. } \\
\quad(2011)\end{array}$ \\
\hline pBBR1MCS2::PphaC-mCherry-n1 & $\begin{array}{l}\text { Broad host range vector for construction of gene fusions with } m \text { Cherry, confers } \mathrm{Km}^{\mathrm{r}} \text {, } \\
\text { constitutive expression from PphaC }\end{array}$ & $\begin{array}{l}\text { Pfeiffer et al. } \\
\quad(2011)\end{array}$ \\
\hline pBBR1MCS2::PPhaC-ppk1 $1_{A T}-m$ Cherry & Constitutive expression of $p p k 1_{A T}-m$ Cherry (atu1 144) & This study \\
\hline pBBR1MCS2::PPhaC-eyfp-ppk1 ${ }_{A T}$ & Constitutive expression of eyfp-ppk2 ${ }_{A T}$ & $\begin{array}{l}\text { Frank and } \\
\text { Jendrossek } \\
(2020)\end{array}$ \\
\hline Ralstonia eutropha $\mathrm{H} 16$ & Wild type, $\mathrm{Km}^{\mathrm{s}}$ & DSMZ428 \\
\hline R. eutropha H16 $\Delta p p k$-all & $\begin{array}{l}\text { Chromosomal deletion of } \Delta p p k 1 a, \Delta p p k 1 b, \Delta p p k 2 a, \Delta p p k 2 b, \Delta p p k 2 c, \Delta p p k 2 d \text {, } \\
\Delta p p k 2 e(A 0104, B 1019, A 0226, A 0997, A 1212, A 0997, A 1271, A 1979), \mathrm{Km}^{\mathrm{s}} \\
\text { polyP deficient }\end{array}$ & $\begin{array}{l}\text { Tumlirsch and } \\
\text { Jendrossek } \\
\text { (2017) }\end{array}$ \\
\hline
\end{tabular}

Kanamycin resistance $\left(\mathrm{Km}^{\mathrm{r}}\right)$ and sensitivity $\left(\mathrm{Km}^{\mathrm{s}}\right)$ 


\section{Purification of PPK1 $1_{\mathrm{AT}}$ and $\mathrm{PPK} 2_{\mathrm{AT}}$ and PPK activity assays}

Purifications of PPK $1_{\mathrm{AT}}$ with a C-terminal and PPK $2_{\mathrm{AT}}$ with an N-terminal hexa-histidine tag were done as previously described for PPK2c of Ralstonia eutropha (Hildenbrand et al. 2019). Purified PPK proteins $(1-4 \mathrm{mg} / \mathrm{ml})$ were stored on ice directly in elution buffer ( $\mathrm{pH} 8.0$ (composition see below) without any further treatment $(250 \mathrm{mM}$ imidazole, $300 \mathrm{mM}$ $\mathrm{NaCl}$ and $50 \mathrm{mM} \mathrm{NaH}_{2} \mathrm{PO}_{4}$ ). PPK activity assays and reaction product determination via HPLC were performed as described in detail previously (Hildenbrand et al. 2020).

Reaction conditions for the formation of oligophosphorylated nucleosides by PPK2 ${ }_{\mathrm{AT}}$ and HPLC-MS/MS analysis Samples

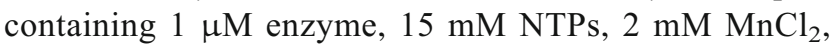
and $0.1 \mathrm{M}$ Tris- $\mathrm{HCl}$ buffer ( $\mathrm{pH}$ 7-8) were incubated for times as indicated $\left(30 \mathrm{~min}\right.$ up to $48 \mathrm{~h}$ at $30^{\circ} \mathrm{C}$ ). Alternatively, $1 \mu \mathrm{M}$ PPK $2_{\mathrm{AT}}$ was incubated with $2 \mathrm{mM}$ NDP (or dTDP [TDP not available]) and $9 \mathrm{mM}$ polyP in assay buffer (0.1 M Tris- $\mathrm{HCl}$ Buffer, $\left.\mathrm{pH} 8,2 \mathrm{mM} \mathrm{MnCl}{ }_{2}\right)$ for times as indicated. The reactions were terminated by heating of the assay mixture to $95{ }^{\circ} \mathrm{C}$ for $3 \mathrm{~min}$. For later use, the samples were stored at $-20{ }^{\circ} \mathrm{C}$ or measured directly. Samples were thawed on ice and centrifugated for $15 \mathrm{~min}$ at $20,000 \mathrm{~g}$ and $4{ }^{\circ} \mathrm{C}$. Targeted LC-MS measurements were performed with enhanced sensitivity on an Agilent 1200 HPLC system coupled with an Agilent 6410B triple quadrupole mass spectrometer (QQQ). Sample preparation and chromatographic separation of nucleoside phosphates by bicratic polymer-based zwitterionic hydrophilic interaction chromatography (ZIC-pHILIC) were performed as previously described (Feith et al. 2019; Hildenbrand et al. 2020) with following modifications: Mobile phases (constant flow rate of $0.2 \mathrm{ml} \mathrm{min}^{-1}$ ) were composed of aqueous buffer solutions (10 mM ammonium acetate, $\mathrm{pH} 9.2)$ with $90 \%(\mathrm{v} / \mathrm{v})$ acetonitrile for eluent $\mathrm{A}$ and $10 \%(\mathrm{v} / \mathrm{v})$ acetonitrile for eluent $\mathrm{B}$, using the following program for gradient elution: isocratic hold $0 \% \mathrm{~B}$ for $1 \mathrm{~min}$, linear gradient from $0 \% \mathrm{~B}$ to $70 \% \mathrm{~B}$ for $19 \mathrm{~min}$, linear gradient from $70 \%$ B to $100 \%$ B for $2 \mathrm{~min}$, isocratic hold $100 \%$ B for $2.5 \mathrm{~min}$, linear gradient from $100 \%$ B to $0 \%$ B for $4 \mathrm{~min}$, and equilibration to starting conditions by an isocratic hold $0 \%$ B for $12 \mathrm{~min}$. Nucleoside mono-, di-, and triphosphates were detected in negative ionization mode (ESI-) with high sensitivity in selected ion monitoring (SIM) mode based on pre-optimized precursor ion transitions with a mass resolution of $0.3 \mathrm{u}$ and associated MS parameters (Teleki et al. 2015). Higher oligophosphorylated nucleosides were detected by calculated precursor ion transitions and transferred MS parameters. System control, acquisition, and data analysis were obtained by using commercial MassHunter B.07.00 software.
Toluidine staining of polyP after polyacrylamide gel electrophoresis

Enzymatically produced polyP (by (PPK $1_{\mathrm{AT}}$ or PPK $2_{\mathrm{AT}}$ ) was separated by electrophoresis in $15 \%$ poly acrylamide gels and stained with toluidine blue according to (Losito et al. 2009). A synthetic polyP standard with $\approx 100 \mathrm{P}_{\mathrm{i}}$ residues in average (gift of A. Saidari) was used as standard. PolyP concentrations in this contribution always refer to the concentration of the monomeric phosphate $\left(\mathrm{P}_{\mathrm{i}}\right)$.

\section{PolyP quantification}

The amount of polyP was quantified after polyP extraction followed by digestion to phosphate with exopolyphosphatase and subsequent phosphate determination (malachinte green assay) as recently summarized in (Christ et al. 2020b).

\section{Results}

Purification of polyP kinases The two polyP kinase genes of A. tumefaciens $\left(p p k 1_{A T}\right)$ and $\left(p p k 2_{A T}\right)$ were PCR amplified, cloned in fusion with a hexa-histidine-coding sequence into pET22b or pET28a, respectively, and expressed in E. coli BL21. PPK $1_{\mathrm{AT}}$ and PPK2 $2_{\mathrm{AT}}$ eluted during nickel agarose affinity chromatography of soluble cell extracts at approximately $250 \mathrm{mM}$ imidazole. PPK $1_{\mathrm{AT}}$ and PPK $2_{\mathrm{AT}}$ containing fractions were combined, concentrated, and tested for purity on a polyacrylamide gel (Online resource 1$)$. PPK $1_{\mathrm{AT}}(84.9 \mathrm{kDa})$ was strongly enriched and PPK2 $2_{\mathrm{AT}}(36.2 \mathrm{kDa})$ was almost homogeneous.

Biochemical characterization of PPK1 $1_{A T}$ The substrate specificity of PPK $1_{\mathrm{AT}}$ was analyzed by incubation of PPK $1_{\mathrm{AT}}$ with ATP, GTP, CTP, dTTP, or UTP for 30 min and subsequent determination of the respective nucleotide compositions by HPLC. It turned out that the activity of PPK $1_{\mathrm{AT}}$ with NTPs was hardly detectable if low concentrations of NTPs $(2 \mathrm{mM})$ were used. Only at high concentrations of the NTPs $(15 \mathrm{mM})$ and after $24 \mathrm{~h}$ reaction time polyP-forming activity was detected as revealed by formation of NDPs at the expense of NTPs (Online resource 2). The highest activity was determined with the purines ATP and GTP. With GTP as substrate (but not with other NTPs), the formation of polyP was shown by gel electrophoresis and subsequent staining with toluidine (Online resource 3). Presumably, the concentration of formed polyP by the other nucleotides was too low to be detected by toluidine staining.

When PPK $1_{\mathrm{AT}}$ activity was tested in the direction of NTP synthesis from polyP and NDPs, an activity of $0.037 \mu \mathrm{mol}$ formed ATP $/ \mathrm{min} / \mathrm{mg}$ (using the 5-min incubation time) was determined for the conversion of ADP (Fig. 1a) but hardly any 


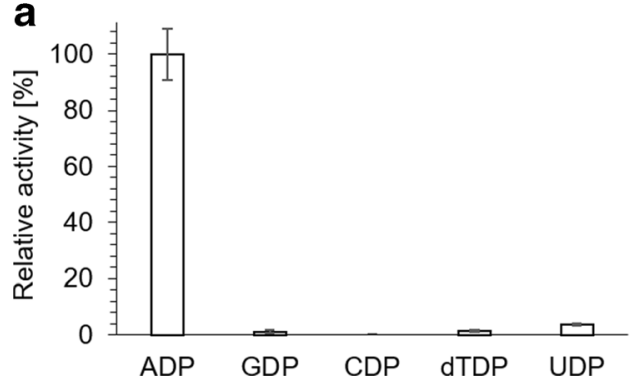

Fig. 1 Enzyme activity of $P P K 1_{A T}$. The reactions were performed in the direction of NTP synthesis from NDPs $(2 \mathrm{mM})$ and polyP $\left(9 \mathrm{mM} \mathrm{P}_{\mathrm{i}}\right)$ and in the presence of $2 \mathrm{mM} \mathrm{MnCl}_{2}$. a Relative activity (\%) after 30-min incubation. The highest activity $(0.004 \mu \mathrm{mol} \mathrm{ADP} / \mathrm{min} / \mathrm{mg}$ expressed as

NTP-synthesizing activities were detected for the other nucleotides (GDP, CDP, UDP, or dTDP). Only by elongation of the assay time to $6 \mathrm{~h}$ the formation of other NTPs from the respective NDPs and polyP became detectable (Fig. 1b). The formation of adenosine tetraphosphate (AP4), however, was not detected (data not shown). AP4 and related NP4s had been previously detected as reaction products of PPKs in earlier studies (see "Discussion" for details and references). PPK $1_{\mathrm{AT}}$ showed good activity in the presence of either calcium or manganese as cofactor. With magnesium, the activity was surprisingly low and no activity was determined in the absence of divalent cations (Fig. 2a). No kinase activity was detected for purified $P P K 1_{\mathrm{AT}}$ with any nucleoside monophosphate and polyP up to $24 \mathrm{~h}$ incubation (data not shown).

Biochemical characterization of PPK2 $2_{\mathrm{AT}}$ Purified PPK2 $2_{\mathrm{AT}}$ (as PPK $1_{\mathrm{AT}}$ ) was not able to phosphorylate NMPs with polyP as phosphate donor (data not shown) and therefore is a member of subgroup 1 of PPK2s according to the PPK2 classification of Motomura et al. (Motomura et al. 2014).

PPK2 $2_{\mathrm{AT}}$ catalyzed the formation of polyP from ATP (NTP) as evident from the decrease of the ATP (NTP) concentration and a concomitant increase of the ADP (NDP) concentrations in PPK assays with purified PPK $2_{\mathrm{AT}}$ after an incubation

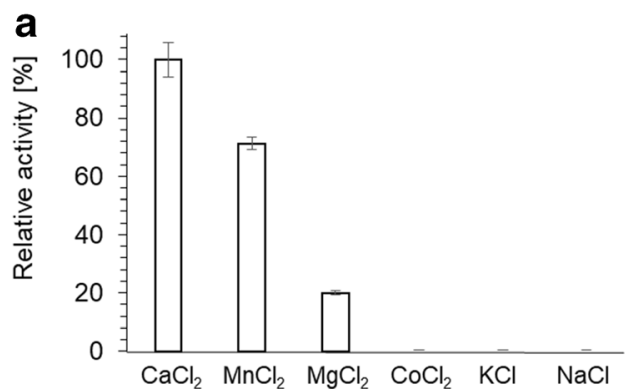

Fig. 2 Enzyme activities of PPK $1_{\mathrm{AT}}$ and $\mathrm{PPK} 2_{\mathrm{AT}}$ with different cations. Activities of PPK $1_{\mathrm{AT}}$ (a) in polyP synthesis direction (from $2 \mathrm{mM}$ ATP, 30 min reaction time) and of PPK $2_{\mathrm{AT}}$ (b) in NTP synthesis direction (from $2 \mathrm{mM}$ ADP, $9 \mathrm{mM}$ polyP, 30-min reaction time) with different cations $(2 \mathrm{mM})$ were determined. The activities were maximal with

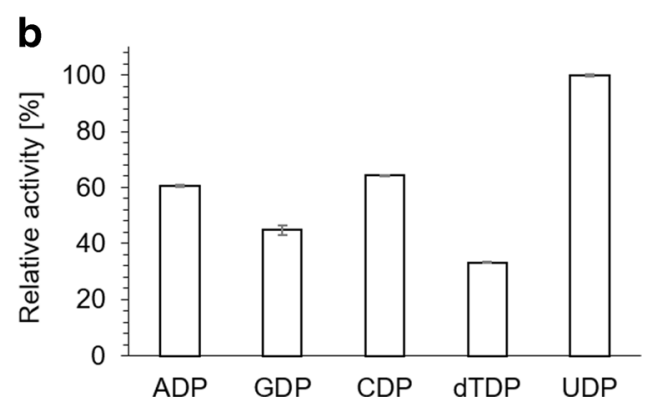

average of the 30-min incubation time) was determined with ADP + polyP and was taken as $100 \%$. b Relative activity (\%) after 6-h incubation. Assays were performed in triplicates; error bars indicate standard deviations

period of $30 \mathrm{~min}$ (Online resource 4). When the reaction products were gel-electrophoretically separated and stained with toluidine blue, strong staining signals were detected as a pink smear and indicated that a mixture of long-chain polyP molecules had been formed (Fig. 3, Online resource 5a). In these experiments, $\mathrm{Mn}^{2+}$ ions were used as cofactor. However, $\mathrm{Mn}^{2+}$ could be replaced by $\mathrm{Mg}^{2+}$ and by $\mathrm{Ca}^{2+}$ but not by monovalent ions such as $\mathrm{Na}^{+}$or $\mathrm{K}^{+}$. Poor activity of $\mathrm{PPK}_{2 \mathrm{AT}}$ was detected in the presence of $\mathrm{Co}^{2+}$ (Fig. 2b).

Similar results were obtained when PPK2 $2_{\mathrm{AT}}$ was incubated with GTP or UTP (instead of ATP) but not with CTP or dTTP as substrates for $30 \mathrm{~min}$. However, after longer incubation time, polyP-toluidine signals became detectable also for dTTP (2 h) and for CTP (24 h) (Fig. 3, Online resource 5b). Interestingly, the polyP-toluidine signals that were clearly detectable after $30 \mathrm{~min}$ for GTP, dTTP $(2 \mathrm{~h})$, and UTP as substrates vanished after longer incubation times; instead, nucleoside phosphates with more than three phosphate residues were detected by HPLC from GTP, dTTP, and UTP (see next chapter for details). This indicated that polyP was used as an intermediate substrate for the synthesis of guanosine-, d-thymidine-, or uridine-oligophosphates in case of the reactions with GTP, dTTP, and UTP. In contrast, even after $48 \mathrm{~h}$ of incubation, the polyP-toluidine signals produced from ATP and CTP were still present and no oligophosphorylated

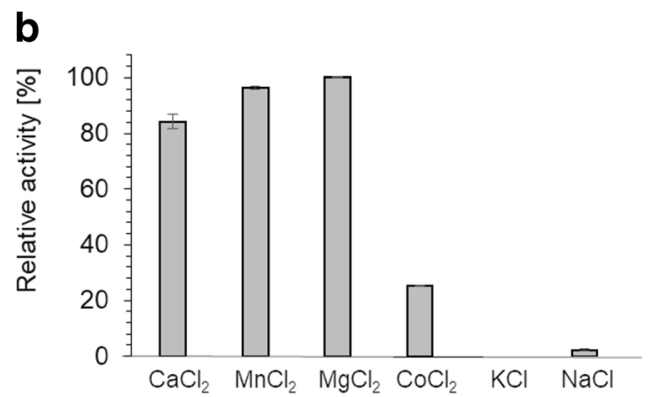

$\mathrm{CaCl}_{2}\left(\mathrm{PPK}_{\mathrm{AT}}, 0.01 \mu \mathrm{mol} \mathrm{ATP} / \mathrm{min} / \mathrm{mg}\right.$ expressed as average of the first $30 \mathrm{~min})$ or with $\mathrm{MgCl}_{2}\left(\mathrm{PPK} 2_{\mathrm{AT}}, 0.09 \mu \mathrm{mol} \mathrm{ADP} / \mathrm{min} / \mathrm{mg}\right.$ ) expressed as average of the first $30 \mathrm{~min}$ ), respectively, and were taken as $100 \%$. Assays were performed in triplicate; error bars indicate standard deviations 


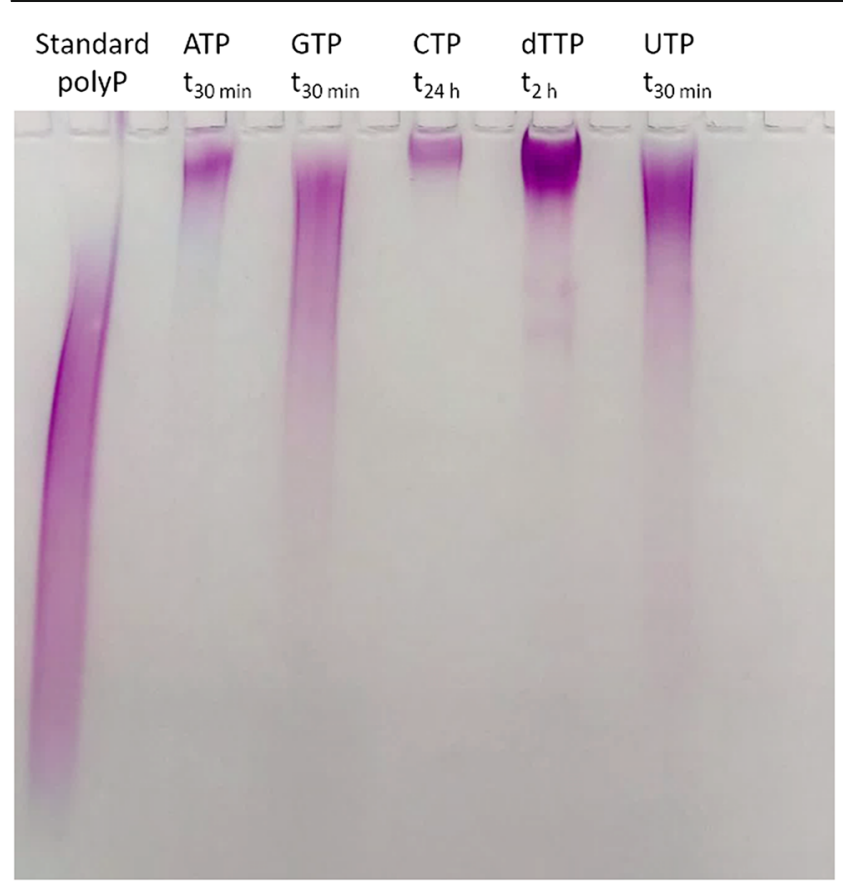

Fig. 3 Separation of PPK $2_{\mathrm{AT}}$-produced polyP by $\mathrm{PAGE}$ and subsequent toluidine staining. PolyP (average chain length $\approx 100 \mathrm{P}_{\mathrm{i}}$ residues corresponding to $9 \mathrm{mM} \mathrm{P}$ ) (lane 1), products from $15 \mathrm{mM}$ of ATP after $30 \mathrm{~min}$ (lane 3), GTP after $30 \mathrm{~min}$ (lane 5), CTP after $24 \mathrm{~h}$ (lane 7), dTTP after $2 \mathrm{~h}$ (lane 9) or UTP after 30 min (lane 11), and controls with no NTP (lane 2) or without PPK2 $2_{\mathrm{AT}}$ (lane 13). Note the products were obtained after different assay times. For direct comparison of products after $30 \mathrm{~min}$ and $24 \mathrm{~h}$, see Online resource $5 \mathrm{a}$ and $5 \mathrm{~b}$

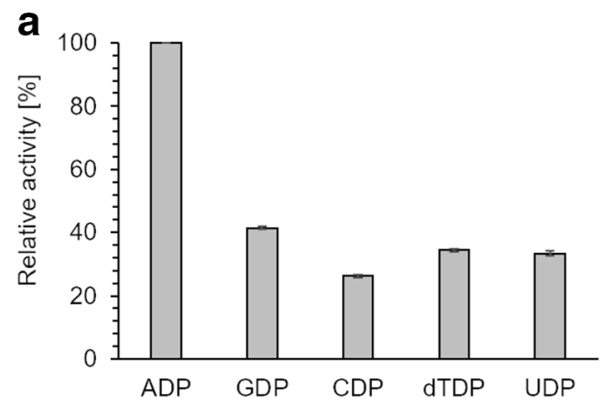

b
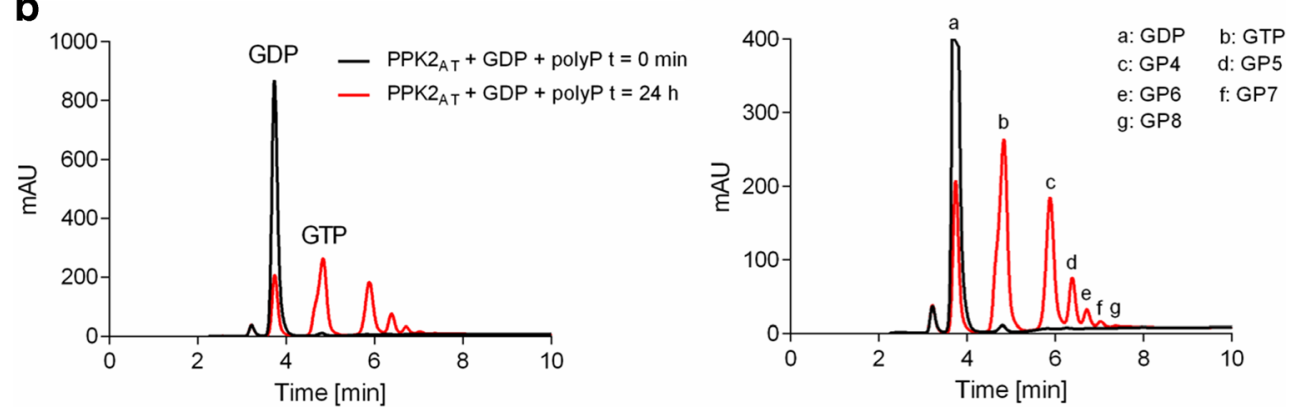

Fig. 4 a Substrate specificity of $P P K 2_{\mathrm{AT}}$. PPK $2_{\mathrm{AT}}$ was assayed in the direction of NTP synthesis from NDP $(2 \mathrm{mM})$ and polyP $\left(9 \mathrm{mM}\right.$ as $\left.\mathrm{P}_{\mathrm{i}}\right)$ with $\mathrm{MnCl}_{2}$ as cofactor for $30 \mathrm{~min}$. Highest activity was determined for ADP and polyP $(0.097 \mu \mathrm{mol} \mathrm{ADP} / \mathrm{min} / \mathrm{mg})$ and was taken as $100 \%$. Assays were performed in triplicate; error bars indicate standard deviations. b Formation of oligophosphorylated nucleosides by $\mathrm{PPK} 2_{\mathrm{AT}}$. Educts and products of PPK2 $2_{\mathrm{AT}}$-catalyzed reactions after $24 \mathrm{~h}$ oligophosphorylated guanosine nucleosides (GP4-GP8) nucleotides (except NP4) were detected with ATP and CTP by HPLC and UV-vis detection (for overview see Online resource 6).

PPK2 ${ }_{\text {AT }}$ phosphorylates NDPs with polyP as phosphor donor and produces NTPs and nucleoside oligophosphates The identification of HPLC signals after prolonged incubation of some NTPs with PPK2 AT that most likely corresponded to oligophosphorylated nucleosides prompted us to investigate whether these assumed oligophosphorylated nucleosides were also formed from NDPs in the presence of polyP. To this end, purified PPK 2 AT was incubated with ADP, GDP, CDP, dTDP, or UDP (each $2 \mathrm{mM}$ ) in the presence of $9 \mathrm{mM}$ polyP for 24 h. Analysis of the products by HPLC revealed that the concentrations of the respective NDPs were substantially reduced (Fig. 4a) and the concentrations the corresponding NTPs were increased. Additional peaks appeared in the HPLC chromatograms of all tested NDPs at higher retention time than that of the respective NTP in each assay and corresponded to adenosine tetraphosphate (AP4), guanosine tetraphosphate (GP4), cytosine tetraphosphate (CP4), desoxy-thymidine tetraphosphate (dTP4), and uridine tetraphosphate (UP4) (Online resource 6) as it has been previously shown for other PPK2s. Apparently, PPK2 $2_{\mathrm{AT}}$ is a member of the growing

of incubation of GDP and polyP were analyzed by HPLC. The left image shows the concentrations of guanosine nucleotides before ( 0 min, black) and after the addition of PPK $2_{\mathrm{AT}}(24 \mathrm{~h}$, red, mAU, milli-absorption units at $254 \mathrm{~nm}$ ). The image on the right is an enlargement revealing the presence of several additional (minor) peaks that correspond to 
group of PPK2s that catalyzes the formation of nucleoside tetraphosphates from NDPs and polyP (see below for more details and references). Furthermore, the HPLC chromatograms of the PPK2 $2_{\mathrm{AT}}$ assays showed even more additional peaks at higher retention times than the respective NP4s for the reactions with GDP, CDP, dTDP, and UDP (exemplarily shown for the reaction with GDP and polyP in Fig. 4b, all other chromatograms in Online resource 6). Assuming that each peak at higher retention time than the respective NTP corresponds to molecules with one more phosphate group, this would mean that PPK2 ${ }_{\text {AT }}$ can catalyze the formation of guanosine oligophosphates (GP4-GP8), cytosine oligophosphates (CP4-CP8), desoxy-thymidine oligophosphates (TP4TP8), and uridine oligophosphates (UP4-UP7). The retention times of these additional peaks were identical to the retention times of the additional peaks that had been detected after prolonged incubation of PPK $2_{\mathrm{AT}}$ with GTP, dTTP, or UTP (see above). We assume that these peaks represent nucleotides with a higher number of phosphate residues than four (see Online resource 7 for summary). Nucleotides with four and five phosphate residues have been previously described as reaction products of PPKs (Mordhorst et al. 2019) but higher phosphorylated nucleosides have not yet been described.

\section{Identification of nucleoside oligophosphates by ZIC- pHILIC-MS/MS}

To verify that the observed products really represent the postulated oligophosphorylated nucleosides, the products of the PPK $2_{\mathrm{AT}}$-catalyzed reaction with NTPs were analyzed by HPLC and HPLC-MS/MS. Figure 5 shows the products of the reaction of PPK $2_{\mathrm{AT}}$ with NTPs separated by HPLC. Again, peaks appeared at higher retention times than the corresponding NTPs and were identified as oligophosphorylated nucleotides by ZIC-pHILIC-MS/ MS. Notably, the deduced masses perfectly matched the expected masses of guanosine tetra-, penta-, hexa-, hepta-, and octa-phosphate each with mass increments of 80 (corresponding to one phosphate unit in polyP; see Table 2). The MS detector even detected molecules with $\mathrm{m} / \mathrm{z}$ values that corresponded to guanosine nonaphosphate (GP9) and guanosine deca-phosphate (GP10), however, with insufficient signal-to-noise ratios. The signal-to-noise ratios were too low for GP9 and GP10 to allow a reliable identification and the concentrations of the higher phosphorylated nucleosides were too low to be visible in the HPLC UV-vis detection. Analog results were obtained for the products of PPK $2_{\mathrm{AT}}$ with the other nucleotides (ATP, GTP, CTP, dTTP, and UTP). With each nucleotide, $\mathrm{m} / \mathrm{z}$ signals for up to the octa- phosphorylated nucleosides (and up to the nonaphosphorylated nucleotide in case of ATP) were clearly detected by ZIC-pHILIC-MS/MS. For a summary of all identified nucleotides, see Table 2 and Online resource 7 and 8 . In summary, $\mathrm{PPK} 2_{\mathrm{AT}}$ catalyzes the transfer of multiple $\mathrm{P}_{\mathrm{i}}$ residues from polyP to NDPs with up to the nonaphosphorylated nucleosides as products. Presumably, nucleotides with even more phosphate residues than eight will become detectable by variation of the assay parameters and/or optimization of the MS detection parameters.

Expression of $p p k 1_{A T}$ and $p p k 2_{A T}$ in polyP-deficient backgrounds To test the function of the A. tumefaciens ppk genes in vivo, we expressed the $p p k 1_{A T}$ and $p p k 2_{A T}$ genes as fusions with the enhanced yellow fluorescent gene (eyfp) (or with $m$ Cherry) in a polyP-deficient background of A. tumefaciens $\left(\Delta p p k 1_{A T}, p p k 2_{A T}\right)$ and $R$. eutropha ( $\Delta p p k$-all, with all seven $p p k$ genes deleted). Expression of $p p k 1_{A T}$ restored the formation of polyP granules in A. tumefaciens $\left(\Delta p p k 1_{A T}, p p k 2_{A T}\right)$ (Online resource 9) and confirmed that PPK1 $1_{\mathrm{AT}}$ is able to form polyP in vivo. A similar result was obtained when $p p k 1_{A T}$ was expressed in $R$. eutropha $\Delta p p k$-all (Fig. 6b). To our surprise, the expression of $p p k 2_{A T}$ also resulted in restoration of polyP granule synthesis in the polyP-deficient R. eutropha background (Fig. 6c) but not in A. tumefaciens $\left(\Delta p p k 1_{A T}, p p k 2_{A T}\right)$ (Online resource 9). These results confirmed that both PPKs of A. tumefaciens principally are able to catalyze the formation of polyP in vivo. In most cells, the formed fusion proteins (eYFP-PPK2 $2_{\mathrm{AT}}$ ) colocalized with DAPI-stained polyP granules in both species. However, $\mathrm{PPK}_{\mathrm{AT}}-\mathrm{mCherry}$ signals were elliptically shaped and were located near the cell pole in A. tumefaciens sometimes-but not always - in close proximity to a formed polyP granule (Online resource 9). In R. eutropha $\Delta p p k$-all, the same construct was distributed more or less homogenously in the whole cell around the polyP granules (Fig. 6b), but did not colocalize with them.

\section{Discussion}

This activity and substrate specificity determinations in our study showed that PPK $1_{\mathrm{AT}}$ is a typical type 1 PPK (Rao et al. 2009) having a preference (or high affinity) for adenine nucleotides and that PPK $2_{\mathrm{AT}}$ is a member of the subtype 1 group of PPK2s with specificity for NDPs but not for NMPs as it had been previously postulated by Motomura et al. (2014) from amino acid sequence analysis. PPK2 ${ }_{\mathrm{AT}}$ has the so far unique property to transfer multiple phosphate groups to GDP, dTDP, or UDP (and to lower extent also to ADP and CDP) and to form oligophosphorylated products up to the octaphosphorylated nucleosides or up to AP9 in case of adenine nucleotides. So far, only tetra- or penta-phosphorylated 
Table 2 Results and parameters of HILIC-QQQ-MS/MS measurements of nucleotide species in PPK2 ${ }_{\mathrm{AT}}$ assays and standard mixtures

\begin{tabular}{|c|c|c|c|c|c|c|c|c|c|}
\hline \multicolumn{2}{|c|}{ Nucleotides } & \multicolumn{3}{|c|}{ MS/MS parameters (SIM) } & \multicolumn{4}{|c|}{ HILIC-QQQ-SIM results } & \multirow{3}{*}{$\begin{array}{l}\text { HPLC results } \\
\text { PPK } 2_{\mathrm{AT}} \text { assay } \\
t_{\mathrm{R}}^{*}(\mathrm{~min})\end{array}$} \\
\hline \multirow[t]{2}{*}{ Abbr. } & \multirow[t]{2}{*}{ Sum formula } & \multirow{2}{*}{$\begin{array}{l}\text { ESI } \\
\text { Polarity }\end{array}$} & \multicolumn{2}{|c|}{ Precursor } & \multicolumn{2}{|c|}{$\mathrm{PPK} 2_{\mathrm{AT}}$ assay } & \multicolumn{2}{|c|}{$100 \mu \mathrm{M}$ standard mix } & \\
\hline & & & Species & $m / z(\mathrm{u})$ & Area (Cts) & $t_{\mathrm{R}}^{*}(\min )$ & Area (Cts) & $t_{\mathrm{R}}^{*}(\min )$ & \\
\hline GMP & $\mathrm{C}_{10} \mathrm{H}_{14} \mathrm{~N}_{5} \mathrm{O}_{8} \mathrm{P}$ & {$[-]$} & {$[\mathrm{M}-\mathrm{H}]^{-}$} & 362 & $1.89 \mathrm{E}+07$ & 17.63 & $6.82 \mathrm{E}+07$ & 17.59 & 3.1 \\
\hline GDP & $\mathrm{C}_{10} \mathrm{H}_{15} \mathrm{~N}_{5} \mathrm{O}_{11} \mathrm{P}_{2}$ & {$[-]$} & {$[\mathrm{M}-\mathrm{H}]^{-}$} & 442 & $6.43 \mathrm{E}+08$ & 19.27 & $1.73 \mathrm{E}+08$ & 19.33 & 3.3 \\
\hline GTP & $\mathrm{C}_{10} \mathrm{H}_{16} \mathrm{~N}_{5} \mathrm{O}_{14} \mathrm{P}_{3}$ & {$[-]$} & {$[\mathrm{M}-\mathrm{H}]^{-}$} & 522 & $4.64 \mathrm{E}+08$ & 20.64 & $1.58 \mathrm{E}+08$ & 20.76 & 4.0 \\
\hline GP4 & $\mathrm{C}_{10} \mathrm{H}_{17} \mathrm{~N}_{5} \mathrm{O}_{17} \mathrm{P}_{4}$ & {$[-]$} & {$[\mathrm{M}-\mathrm{H}]^{-}$} & 602 & $2.39 \mathrm{E}+08$ & 22.16 & & & 4.5 \\
\hline GP5 & $\mathrm{C}_{10} \mathrm{H}_{18} \mathrm{~N}_{5} \mathrm{O}_{20} \mathrm{P}_{5}$ & {$[-]$} & {$[\mathrm{M}-\mathrm{H}]^{-}$} & 682 & $3.55 \mathrm{E}+07$ & 23.82 & & & 5.2 \\
\hline GP6 & $\mathrm{C}_{10} \mathrm{H}_{19} \mathrm{~N}_{5} \mathrm{O}_{23} \mathrm{P}_{6}$ & {$[-]$} & {$[\mathrm{M}-\mathrm{H}]^{-}$} & 762 & $5.49 \mathrm{E}+06$ & 25.32 & & & 5.8 \\
\hline GP7 & $\mathrm{C}_{10} \mathrm{H}_{20} \mathrm{~N}_{5} \mathrm{O}_{26} \mathrm{P}_{7}$ & {$[-]$} & {$[\mathrm{M}-\mathrm{H}]^{-}$} & 842 & $5.84 \mathrm{E}+05$ & 26.84 & & & 6.3 \\
\hline GP8 & $\mathrm{C}_{10} \mathrm{H}_{21} \mathrm{~N}_{5} \mathrm{O}_{29} \mathrm{P}_{8}$ & {$[-]$} & {$[\mathrm{M}-\mathrm{H}]^{-}$} & 922 & $7.31 \mathrm{E}+04$ & 27.97 & & & 6.7 \\
\hline dTMP & $\mathrm{C}_{10} \mathrm{H}_{15} \mathrm{~N}_{2} \mathrm{O}_{8} \mathrm{P}$ & {$[-]$} & {$[\mathrm{M}-\mathrm{H}]^{-}$} & 321 & $<\mathrm{LOD}^{* *}$ & na*** & $1.66 \mathrm{E}+08$ & 14.10 & 4.6 \\
\hline dTDP & $\mathrm{C}_{10} \mathrm{H}_{16} \mathrm{~N}_{2} \mathrm{O}_{11} \mathrm{P}_{2}$ & {$[-]$} & {$[\mathrm{M}-\mathrm{H}]^{-}$} & 401 & $6.76 \mathrm{E}+05$ & 16.36 & $2.47 \mathrm{E}+08$ & 16.35 & 5.5 \\
\hline dTTP & $\mathrm{C}_{10} \mathrm{H}_{17} \mathrm{~N}_{2} \mathrm{O}_{14} \mathrm{P}_{3}$ & {$[-]$} & {$[\mathrm{M}-\mathrm{H}]^{-}$} & 481 & $2.21 \mathrm{E}+07$ & 18.04 & $1.84 \mathrm{E}+08$ & 17.86 & 6.1 \\
\hline dTP4 & $\mathrm{C}_{10} \mathrm{H}_{18} \mathrm{~N}_{2} \mathrm{O}_{17} \mathrm{P}_{4}$ & {$[-]$} & {$[\mathrm{M}-\mathrm{H}]^{-}$} & 561 & $4.94 \mathrm{E}+08$ & 20.89 & & & 6.9 \\
\hline dTP5 & $\mathrm{C}_{10} \mathrm{H}_{19} \mathrm{~N}_{2} \mathrm{O}_{20} \mathrm{P}_{5}$ & {$[-]$} & {$[\mathrm{M}-\mathrm{H}]^{-}$} & 641 & $1.08 \mathrm{E}+08$ & 22.58 & & & 7.3 \\
\hline dTP6 & $\mathrm{C}_{10} \mathrm{H}_{20} \mathrm{~N}_{2} \mathrm{O}_{23} \mathrm{P}_{6}$ & {$[-]$} & {$[\mathrm{M}-\mathrm{H}]-$} & 721 & $5.99 \mathrm{E}+07$ & 24.10 & & & 7.5 \\
\hline dTP7 & $\mathrm{C}_{10} \mathrm{H}_{21} \mathrm{~N}_{2} \mathrm{O}_{26} \mathrm{P}_{7}$ & {$[-]$} & {$[\mathrm{M}-\mathrm{H}]^{-}$} & 801 & $2.03 \mathrm{E}+07$ & 25.49 & & & 7.7 \\
\hline dTP8 & $\mathrm{C}_{10} \mathrm{H}_{22} \mathrm{~N}_{2} \mathrm{O}_{29} \mathrm{P}_{8}$ & {$[-]$} & {$[\mathrm{M}-\mathrm{H}]^{-}$} & 881 & $7.33 \mathrm{E}+06$ & 26.76 & & & 7.9 \\
\hline AMP & $\mathrm{C}_{10} \mathrm{H}_{14} \mathrm{~N}_{5} \mathrm{O}_{7} \mathrm{P}$ & {$[-]$} & {$[\mathrm{M}-\mathrm{H}]^{-}$} & 346 & $1.67 \mathrm{E}+08$ & 15.09 & $1.36 \mathrm{E}+08$ & 15.09 & 4.7 \\
\hline ADP & $\mathrm{C}_{10} \mathrm{H}_{15} \mathrm{~N}_{5} \mathrm{O}_{10} \mathrm{P}_{2}$ & {$[-]$} & {$[\mathrm{M}-\mathrm{H}]^{-}$} & 426 & $4.63 \mathrm{E}+08$ & 16.69 & $1.76 \mathrm{E}+08$ & 16.90 & 6.4 \\
\hline ATP & $\mathrm{C}_{10} \mathrm{H}_{16} \mathrm{~N}_{5} \mathrm{O}_{13} \mathrm{P}_{3}$ & {$[-]$} & {$[\mathrm{M}-\mathrm{H}]^{-}$} & 506 & $1.02 \mathrm{E}+09$ & 18.44 & $1.85 \mathrm{E}+08$ & 18.32 & 7.8 \\
\hline AP4 & $\mathrm{C}_{10} \mathrm{H}_{17} \mathrm{~N}_{5} \mathrm{O}_{16} \mathrm{P}_{4}$ & {$[-]$} & {$[\mathrm{M}-\mathrm{H}]^{-}$} & 586 & $2.75 \mathrm{E}+08$ & 19.96 & & & 8.2 \\
\hline AP5 & $\mathrm{C}_{10} \mathrm{H}_{18} \mathrm{~N}_{5} \mathrm{O}_{19} \mathrm{P}_{5}$ & {$[-]$} & {$[\mathrm{M}-\mathrm{H}]^{-}$} & 666 & $1.60 \mathrm{E}+08$ & 22.26 & & & na \\
\hline AP6 & $\mathrm{C}_{10} \mathrm{H}_{19} \mathrm{~N}_{5} \mathrm{O}_{22} \mathrm{P}_{6}$ & {$[-]$} & {$[\mathrm{M}-\mathrm{H}]^{-}$} & 746 & $8.38 \mathrm{E}+06$ & 23.61 & & & na \\
\hline AP7 & $\mathrm{C}_{10} \mathrm{H}_{20} \mathrm{~N}_{5} \mathrm{O}_{25} \mathrm{P}_{7}$ & {$[-]$} & {$[\mathrm{M}-\mathrm{H}]^{-}$} & 826 & $2.08 \mathrm{E}+06$ & 24.82 & & & na \\
\hline AP8 & $\mathrm{C}_{10} \mathrm{H}_{21} \mathrm{~N}_{5} \mathrm{O}_{28} \mathrm{P}_{8}$ & {$[-]$} & {$[\mathrm{M}-\mathrm{H}]^{-}$} & 906 & $3.22 \mathrm{E}+05$ & 26.10 & & & na \\
\hline AP9 & $\mathrm{C}_{10} \mathrm{H}_{22} \mathrm{~N}_{5} \mathrm{O}_{31} \mathrm{P}_{9}$ & {$[-]$} & {$[\mathrm{M}-\mathrm{H}]^{-}$} & 986 & $1.47 \mathrm{E}+05$ & 27.27 & & & na \\
\hline UMP & $\mathrm{C}_{9} \mathrm{H}_{13} \mathrm{~N}_{2} \mathrm{O}_{9} \mathrm{P}$ & {$[-]$} & {$[\mathrm{M}-\mathrm{H}]^{-}$} & 323 & $1.59 \mathrm{E}+06$ & 16.23 & $1.08 \mathrm{E}+08$ & 16.23 & 2.9 \\
\hline UDP & $\mathrm{C}_{9} \mathrm{H}_{14} \mathrm{~N}_{2} \mathrm{O}_{12} \mathrm{P}_{2}$ & {$[-]$} & {$[\mathrm{M}-\mathrm{H}]^{-}$} & 403 & $2.27 \mathrm{E}+07$ & 17.92 & $1.98 \mathrm{E}+08$ & 18.15 & 3.1 \\
\hline UTP & $\mathrm{C}_{9} \mathrm{H}_{15} \mathrm{~N}_{2} \mathrm{O}_{15} \mathrm{P}_{3}$ & {$[-]$} & {$[\mathrm{M}-\mathrm{H}]^{-}$} & 483 & $1.69 \mathrm{E}+07$ & 19.27 & $2.35 \mathrm{E}+08$ & 19.57 & 3.8 \\
\hline UP4 & $\mathrm{C}_{9} \mathrm{H}_{16} \mathrm{~N}_{2} \mathrm{O}_{18} \mathrm{P}_{4}$ & {$[-]$} & {$[\mathrm{M}-\mathrm{H}]^{-}$} & 563 & $1.27 \mathrm{E}+07$ & 20.98 & & & 4.4 \\
\hline UP5 & $\mathrm{C}_{9} \mathrm{H}_{17} \mathrm{~N}_{2} \mathrm{O}_{21} \mathrm{P}_{5}$ & {$[-]$} & {$[\mathrm{M}-\mathrm{H}]^{-}$} & 643 & $1.91 \mathrm{E}+06$ & 22.56 & & & 5.2 \\
\hline UP6 & $\mathrm{C}_{9} \mathrm{H}_{18} \mathrm{~N}_{2} \mathrm{O}_{24} \mathrm{P}_{6}$ & {$[-]$} & {$[\mathrm{M}-\mathrm{H}]^{-}$} & 723 & $2.16 \mathrm{E}+05$ & 24.10 & & & 5.9 \\
\hline UP7 & $\mathrm{C}_{9} \mathrm{H}_{19} \mathrm{~N}_{2} \mathrm{O}_{27} \mathrm{P}_{7}$ & {$[-]$} & {$[\mathrm{M}-\mathrm{H}]^{-}$} & 803 & $5.75 \mathrm{E}+03$ & 26.04 & & & 6.4 \\
\hline UP8 & $\mathrm{C}_{9} \mathrm{H}_{20} \mathrm{~N}_{2} \mathrm{O}_{30} \mathrm{P}_{8}$ & {$[-]$} & {$[\mathrm{M}-\mathrm{H}]^{-}$} & 883 & $4.78 \mathrm{E}+03$ & 27.12 & & & 6.8 \\
\hline CMP & $\mathrm{C}_{9} \mathrm{H}_{14} \mathrm{~N}_{3} \mathrm{O}_{8} \mathrm{P}$ & {$[-]$} & {$[\mathrm{M}-\mathrm{H}]^{-}$} & 322 & $3.36 \mathrm{E}+07$ & 16.90 & $8.69 \mathrm{E}+07$ & 16.95 & 2.6 \\
\hline $\mathrm{CDP}$ & $\mathrm{C}_{9} \mathrm{H}_{15} \mathrm{~N}_{3} \mathrm{O}_{11} \mathrm{P}_{2}$ & {$[-]$} & {$[\mathrm{M}-\mathrm{H}]^{-}$} & 402 & $6.04 \mathrm{E}+08$ & 18.42 & $1.35 \mathrm{E}+08$ & 18.63 & 3.0 \\
\hline СТP & $\mathrm{C}_{9} \mathrm{H}_{16} \mathrm{~N}_{3} \mathrm{O}_{14} \mathrm{P}_{3}$ & {$[-]$} & {$[\mathrm{M}-\mathrm{H}]^{-}$} & 482 & $6.97 \mathrm{E}+08$ & 19.89 & $1.21 \mathrm{E}+08$ & 20.00 & 3.7 \\
\hline $\mathrm{CP} 4$ & $\mathrm{C}_{9} \mathrm{H}_{17} \mathrm{~N}_{3} \mathrm{O}_{17} \mathrm{P}_{4}$ & {$[-]$} & {$[\mathrm{M}-\mathrm{H}]^{-}$} & 562 & $7.24 \mathrm{E}+07$ & 21.64 & & & na \\
\hline CP5 & $\mathrm{C}_{9} \mathrm{H}_{18} \mathrm{~N}_{3} \mathrm{O}_{20} \mathrm{P}_{5}$ & {$[-]$} & {$[\mathrm{M}-\mathrm{H}]^{-}$} & 642 & $1.50 \mathrm{E}+06$ & 23.25 & & & na \\
\hline CP6 & $\mathrm{C}_{9} \mathrm{H}_{19} \mathrm{~N}_{3} \mathrm{O}_{23} \mathrm{P}_{6}$ & {$[-]$} & {$[\mathrm{M}-\mathrm{H}]^{-}$} & 722 & $4.64 \mathrm{E}+04$ & 24.78 & & & na \\
\hline $\mathrm{CP} 7$ & $\mathrm{C}_{9} \mathrm{H}_{20} \mathrm{~N}_{3} \mathrm{O}_{26} \mathrm{P}_{7}$ & {$[-]$} & {$[\mathrm{M}-\mathrm{H}]^{-}$} & 802 & $<\mathrm{LOD}^{* *}$ & na & & & na \\
\hline CP8 & $\mathrm{C}_{9} \mathrm{H}_{21} \mathrm{~N}_{3} \mathrm{O}_{29} \mathrm{P}_{8}$ & {$[-]$} & {$[\mathrm{M}-\mathrm{H}]^{-}$} & 882 & $<\mathrm{LOD}^{* *}$ & na & & & na \\
\hline
\end{tabular}

*Retention time of the nucleotide species

** Limit of detection

***Not available

Peak areas (Cts) and HILIC retention times ( $\mathrm{min}$ ) were achieved by QQQ-SIM detection $(\mathrm{m} / \mathrm{z} \pm 0.3 \mathrm{u}$ ). Retention times of HPLC measurements (min) are comparatively depicted in the most right column

nucleotides have been detected as reaction products of PPK2 of Meiococcus ruber (Mordhorst et al. 2019). Using A. tumefaciens $\mathrm{PPK} 2_{\mathrm{AT}}$, the oligophosphorylated nucleosides were formed from the diphosphates in the presence of polyP immediately. In contrast, it took much longer until oligophosphorylated nucleosides became detectable if PPK2 ${ }_{\mathrm{AT}}$ was tested in the direction of polyP synthesis from
NTPs: it was first necessary that polyP molecules were formed before up to the deca-phosphorylated nucleosides became detectable. This finding suggests that PPK2 ${ }_{\mathrm{AT}}$ catalyzes the transfer of short phosphate chains from polyP to NDPs. A multiple transfer of single phosphate residues from polyP to NDPs is also possible. The reaction worked best with GDP, dTDP, or UDP and with lower efficiency also with ADP (up to AP9) or 
Fig. 5 Formation of oligophosphorylated nucleosides by PPK $2_{\mathrm{AT}}$. The reaction products of PPK $2_{\mathrm{AT}}$ after $24 \mathrm{~h}$ of incubation with NDPs in the presence of polyP were analyzed by HPLC. The left image shows the concentrations of nucleotides before ( 0 min, black) and after the addition of PPK2 ${ }_{\mathrm{AT}}(24 \mathrm{~h}$, red, $\mathrm{mAU}$, milli-absorption units at $254 \mathrm{~nm})$. In the enlargement in the image on the right, several additional (minor) peaks became detectable that correspond to oligophosphorylated nucleotides
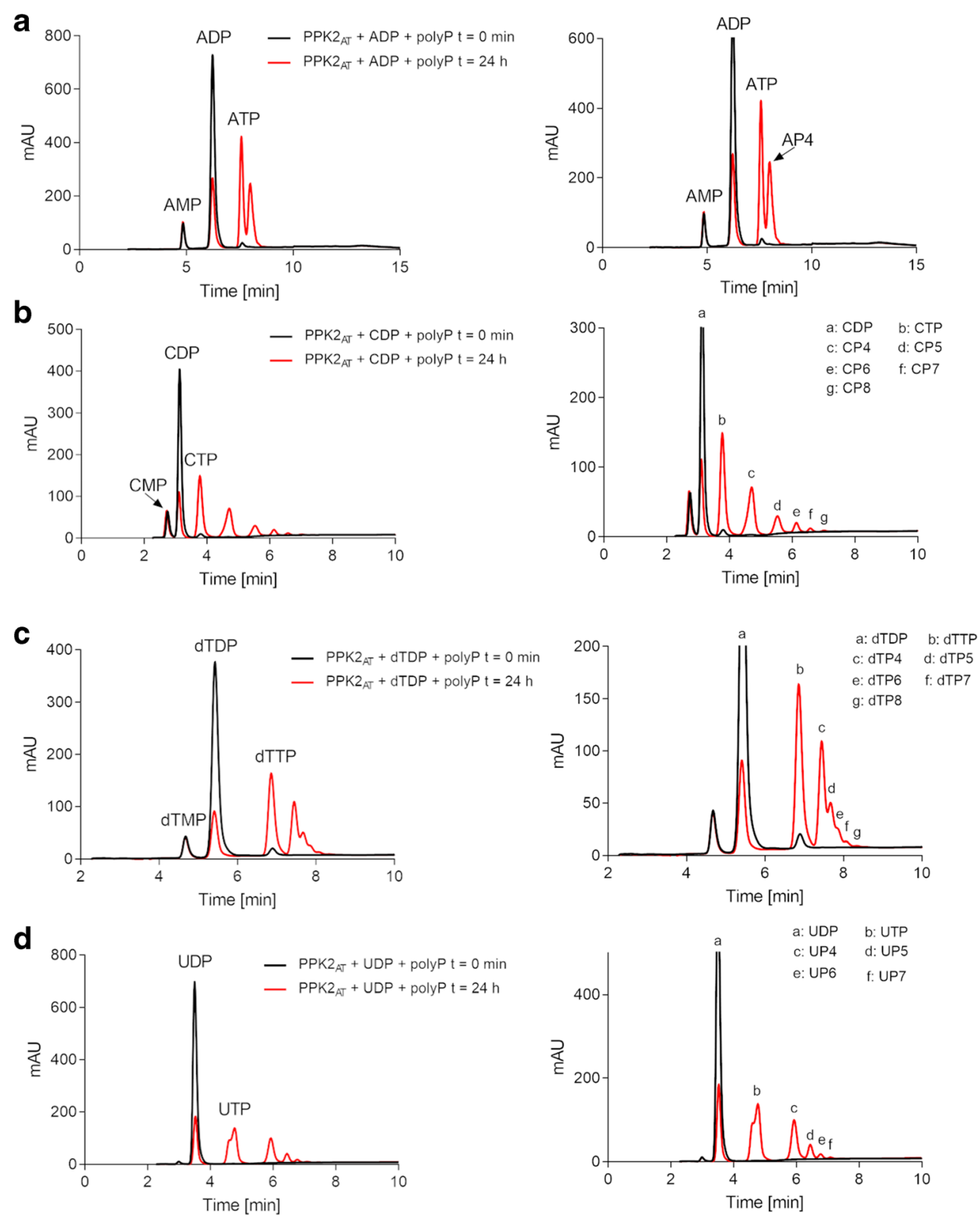

with CDP (up to CP8). We do not know whether the in vitro detected oligophosphorylated nucleosides were also formed in vivo and if they were formed, what physiological function they might fulfill. The in vitro formation of oligophosphorylated nucleosides required the presence of $\mathrm{Mn}^{2+}$ ions that are not likely to be present in millimolar concentrations in vivo. Interestingly, in Myxococcus xanthus, AP4 (and diadenosine tetraphosphate and diadenosine pentaphosphate) have been detected and are formed by the action of some amino acyl tRNA synthetases and by phosphoglycerate kinase (Kimura et al. 2018) suggesting that an astonishing variety of oligophosphorylated nucleotides can be formed in microorganisms in vivo.

PPK2 ${ }_{\mathrm{AT}}$ is a rather unspecific enzyme and converts all tested NDPs to the corresponding NTPs as the main product in the presence of polyP at high rates. This suggests that the in vivo function of PPK2 $2_{\mathrm{AT}}$ is to replenish lowered NTP (and/ or dNTP) pools from previously accumulated polyP during phases of enhanced demand, e.g., during DNA replication or at high transcription rates. This corresponds with previous studies in our lab in which we showed that PPK2 ${ }_{\mathrm{AT}}$ is not necessary for polyP formation and that $\Delta p p k 1_{A T}$ (Frank and Jendrossek 2020) deletion strains were not able to form polyP granules. Accordingly, a $\Delta p p k 2_{A T}$ deletion strain produced slightly more polyP than the wild type presumably because the polyP-consuming activity of PPK2 $2_{\mathrm{AT}}$ is absent. The reason why PPK2 $2_{\mathrm{AT}}$ was able to restore the formation of polyP granules in $R$. eutropha but not in A. tumefaciens (despite good in vitro polyP-forming activities of PPK $2_{\mathrm{AT}}$ ) might lie in different in vivo nucleotide concentrations in both strains. 
a

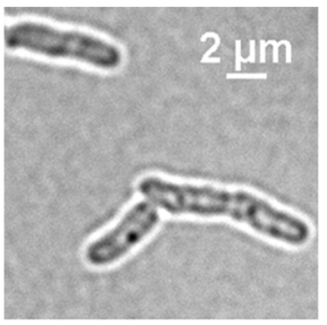

b

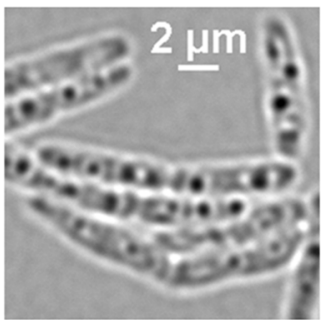

C

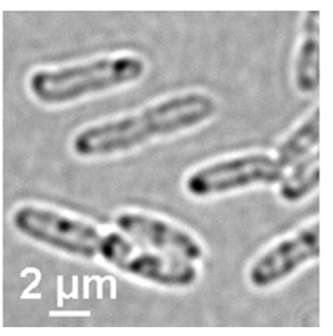

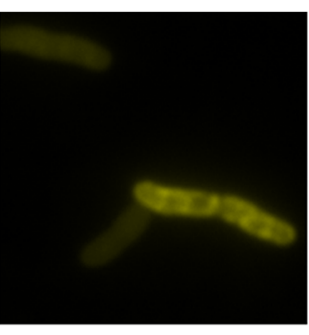
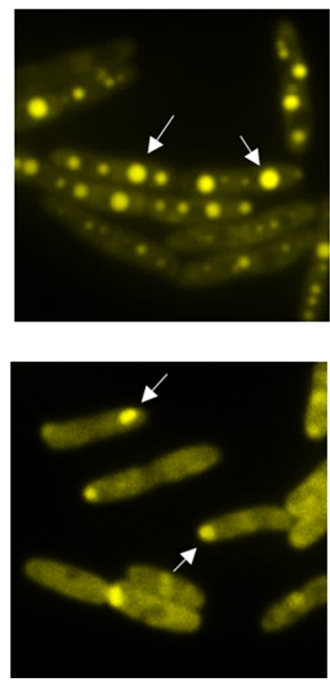
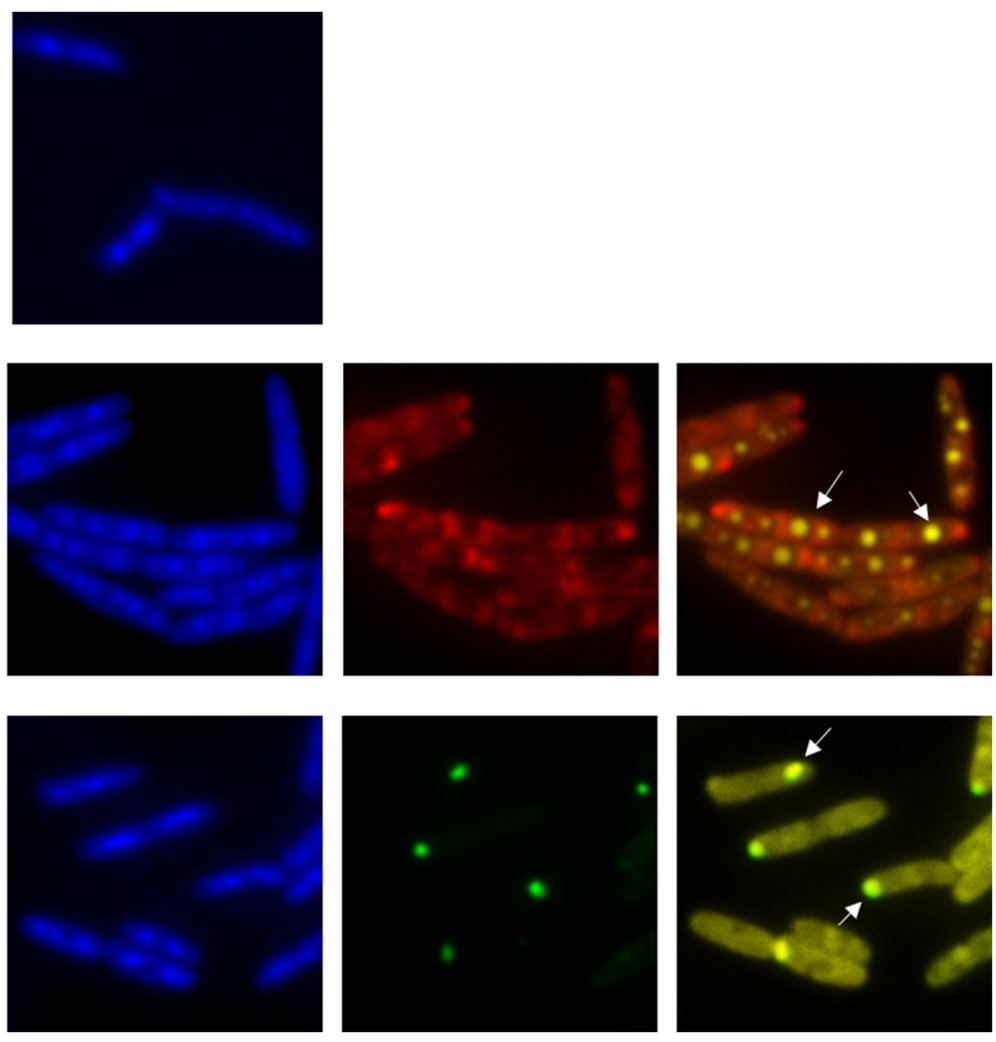

located throughout the cytoplasm. From left to right: bright field, DAPIpolyP channel, DAPI-DNA channel, mCherry channel, merge of DAPIpolyP, and mCherry channel. c $R$. eutropha $\Delta p p k$-all harboring pBBR1MCS2::P phaC-eyfp-ppk2 $2_{A T}$. The cells were able to form DAPIstainable polyP granules at the cell pole that colocalize with the eYFP$\mathrm{PPK} 2_{A T}$ fluorescence signal channel. b $R$. eutropha $\Delta p p k$-all harboring pBBR1MCS2::PphaC$p p k 1_{A T}$-mCherry shows various DAPI-stainable polyP granules distributed over the length of the cell, whereas the mCherry-PPK $1_{\mathrm{AT}}$ signal is

Higher in vivo concentrations of NTPs in R. eutropha compared with A. tumefaciens might allow the formation of polyP from expressed $p p k 2_{A T}$.

Acknowledgments The authors thank Helen Sibold for assisting in some experiments and A. Saidari for providing the polyP standard.

Authors' contributions DJ designed the study and wrote the manuscript. CF performed most experiments, analyzed the data, and prepared the "Material and method" section and the figures. AT conducted HPLCMS/MS and analyzed the MS data. All authors read and approved the manuscript.

Funding Open Access funding is provided by Projekt DEAL. This work was supported by a grant from the Deutsche Forschungsgemeinschaft to DJ and support for CF as an associate member of the RTG1708 (Bacterial survival strategies, University Tübingen).

\section{Compliance with ethical standards}

Conflict of interest The authors declare that they have no conflict of interest.

Ethic approval This article does not contain any studies with human participants or animals performed by any of the authors.
Open Access This article is licensed under a Creative Commons Attribution 4.0 International License, which permits use, sharing, adaptation, distribution and reproduction in any medium or format, as long as you give appropriate credit to the original author(s) and the source, provide a link to the Creative Commons licence, and indicate if changes were made. The images or other third party material in this article are included in the article's Creative Commons licence, unless indicated otherwise in a credit line to the material. If material is not included in the article's Creative Commons licence and your intended use is not permitted by statutory regulation or exceeds the permitted use, you will need to obtain permission directly from the copyright holder. To view a copy of this licence, visit http://creativecommons.org/licenses/by/4.0/.

\section{References}

Ahn KH, Kornberg A (1990) Polyphosphate kinase from Escherichia coli - purification and demonstration of a phosphoenzyme intermediate. J Biol Chem 265:11734-11739

Christ JJ, Smith SA, Willbold S, Morrissey JH, Blank LM (2020a) Biotechnological synthesis of water-soluble food-grade polyphosphate with Saccharomyces cerevisiae. Biotechnol Bioeng 95:555-2099. https://doi.org/10.1002/bit.27337

Christ JJ, Willbold S, Blank LM (2020b) Methods for the analysis of polyphosphate in the life sciences. Anal Chem 92:4167-4176 
Chuang Y-M, Belchis DA, Karakousis PC (2013) The polyphosphate kinase gene $p p k 2$ is required for Mycobacterium tuberculosis inorganic polyphosphate regulation and virulence. MBio 4:e00039e00013. https://doi.org/10.1128/mBio.00039-13

Feith A, Teleki A, Graf M, Favilli L, Takors R (2019) HILIC-enabled $13 \mathrm{C}$ metabolomics strategies: comparing quantitative precision and spectral accuracy of QTOF high- and QQQ low-resolution mass spectrometry. Metabolites 9:63. https://doi.org/10.3390/ metabo9040063

Frank C, Jendrossek D (2020) Acidocalcisomes and polyphosphate granules are different subcellular structures in Agrobacterium tumefaciens. Appl Environ Microbiol 86. https://doi.org/10.1128/ AEM.02759-19

Goodner B, Hinkle G, Gattung S, Miller N, Blanchard M, Qurollo B, Goldman BS, Cao Y, Askenazi M, Halling C, Mullin L, Houmiel K, Gordon J, Vaudin M, Iartchouk O, Epp A, Liu F, Wollam C, Allinger M, Doughty D, Scott C, Lappas C, Markelz B, Flanagan C, Crowell C, Gurson J, Lomo C, Sear C, Strub G, Cielo C, Slater S (2001) Genome sequence of the plant pathogen and biotechnology agent Agrobacterium tumefaciens C58. Science 294:2323-2328. https://doi.org/10.1126/science.1066803

Gray MJ, Jakob U (2015) Oxidative stress protection by polyphosphate new roles for an old player. Curr Opin Microbiol 24:1-6. https://doi. org/10.1016/j.mib.2014.12.004

Hildenbrand JC, Reinhardt S, Jendrossek D (2019) Formation of an organic-inorganic biopolymer: polyhydroxybutyratepolyphosphate. Biomacromolecules acs.biomac. 9b00208. https:// doi.org/10.1021/acs.biomac.9b00208

Hildenbrand JC, Teleki A, Jendrossek D (2020) A universal polyphosphate kinase: PPK2c of Ralstonia eutropha accepts purine and pyrimidine nucleotides including uridine diphosphate. Appl Microbiol Biotechnol 265:11734-11739. https://doi.org/10.1007/ s00253-020-10706-9

Kimura Y, Tanaka C, Oka M (2018) Identification of major enzymes involved in the synthesis of diadenosine tetraphosphate and/or adenosine tetraphosphate in Myxococcus xanthus. Curr Microbiol 75(7): 811-817. https://doi.org/10.1007/s00284-018-1452-x

Kornberg A, Rao NN, Ault-Riche D (1999) Inorganic polyphosphate: a molecule of many functions. Annu Rev Biochem 68:89-125. https://doi.org/10.1146/annurev.biochem.68.1.89

Kulakovskaya TV, Lichko LP, Ryazanova LP (2014) Diversity of phosphorus reserves in microorganisms. Biochem Mosc 79:1602-1614. https://doi.org/10.1134/S0006297914130100

Lempart J, Jakob U (2019) Role of polyphosphate in amyloidogenic processes. Cold Spring Harb Perspect Biol 11:a034041. https://doi. org/10.1101/cshperspect.a034041

Losito O, Szijgyarto Z, Resnick AC, Saiardi A (2009) Inositol pyrophosphates and their unique metabolic complexity: analysis by gel electrophoresis. PLoS One 4:e5580. https://doi.org/10.1371/journal. pone. 0005580

Mordhorst S, Singh J, Mohr MKF, Hinkelmann R, Keppler M, Jessen HJ, Andexer JN (2019) Several polyphosphate kinase 2 enzymes catalyse the production of adenosine 5'-polyphosphates. Chembiochem 20:1019-1022. https://doi.org/10.1002/cbic.201800704

Motomura K, Hirota R, Okada M, Ikeda T, Ishida T, Kuroda A (2014) A new subfamily of polyphosphate kinase 2 (class III PPK2) catalyzes both nucleoside monophosphate phosphorylation and nucleoside diphosphate phosphorylation. Appl Environ Microbiol 80:26022608. https://doi.org/10.1128/AEM.03971-13
Nikel PI, Chavarria M, Martinez-Garcia E, Taylor AC, de Lorenzo V (2013) Accumulation of inorganic polyphosphate enables stress endurance and catalytic vigour in Pseudomonas putida KT2440. Microb Cell Factories 12:50. https://doi.org/10.1186/1475-2859$12-50$

Ogawa M, Uyeda A, Harada K, Sato Y, Kato Y, Watanabe H, Honda K, Matsuura T (2019) Class III polyphosphate kinase 2 enzymes catalyze the pyrophosphorylation of adenosine-5'-monophosphate. Chembiochem 44:13-2967. https://doi.org/10.1002/cbic. 201900303

Pfeiffer D, Wahl A, Jendrossek D (2011) Identification of a multifunctional protein, PhaM, that determines number, surface to volume ratio, subcellular localization and distribution to daughter cells of poly(3-hydroxybutyrate), PHB, granules in Ralstonia eutropha H16. Mol Microbiol 82:936-951. https://doi.org/10.1111/j.13652958.2011.07869.x

Racki LR, Tocheva EI, Dieterle MG, Sullivan MC, Jensen GJ, Newman DK (2017) Polyphosphate granule biogenesis is temporally and functionally tied to cell cycle exit during starvation in Pseudomonas aeruginosa. Proc Natl Acad Sci U S A 114: 201615575-2016E2449. https://doi.org/10.1073/pnas.1615575114

Rao NN, Gómez-García MR, Kornberg A (2009) Inorganic polyphosphate: essential for growth and survival. Annu Rev Biochem 78:605-647. https://doi.org/10.1146/annurev.biochem. 77.083007.093039

Rashid MH, Kornberg A (2000) Inorganic polyphosphate is needed for swimming, swarming, and twitching motilities of Pseudomonas aeruginosa. Proc Natl Acad Sci U S A 97:4885-4890. https://doi. org/10.1073/pnas.060030097

Rashid MH, Rumbaugh K, Passador L, Davies DG, Hamood AN, Iglewski BH, Kornberg A (2000) Polyphosphate kinase is essential for biofilm development, quorum sensing, and virulence of Pseudomonas aeruginosa. Proc Natl Acad Sci U S A 97:96369641. https://doi.org/10.1073/pnas.170283397

Seufferheld M, Vieira M, Ruiz FA, Rodrigues CO, Moreno S, Docampo $\mathrm{R}$ (2003) Identification of organelles in bacteria similar to acidocalcisomes of unicellular eukaryotes. J Biol Chem 278: 29971-29978. https://doi.org/10.1074/jbc.M304548200

Teleki A, Sánchez-Kopper A, Takors R (2015) Alkaline conditions in hydrophilic interaction liquid chromatography for intracellular metabolite quantification using tandem mass spectrometry. Anal Biochem 475:4-13. https://doi.org/10.1016/j.ab.2015.01.002

Tumlirsch T, Jendrossek D (2017) Proteins with CHADs (conserved histidine $\alpha$-helical domains) are attached to polyphosphate granules in vivo and constitute a novel family of polyphosphate-associated proteins (Phosins). Appl Environ Microbiol 83:e03399-e16-14. https://doi.org/10.1128/AEM.03399-16

Tumlirsch T, Sznajder A, Jendrossek D (2015) Formation of polyphosphate by polyphosphate kinases and its relationship to poly(3-hydroxybutyrate) accumulation in Ralstonia eutropha strain H16. Appl Environ Microbiol 81:8277-8293. https://doi.org/10. 1128/AEM.02279-15

Zhu Y, Huang W, Lee SSK, Xu W (2005) Crystal structure of a polyphosphate kinase and its implications for polyphosphate synthesis. EMBO Rep 6:681-687. https://doi.org/10.1038/sj.embor. 7400448

Publisher's note Springer Nature remains neutral with regard to jurisdictional claims in published maps and institutional affiliations. 